\title{
Efficacy of Some Biotic and Abiotic Factors in Controlling Common Bean Rust Disease Caused by Uromyces appendiculatus
}

\section{Ismail, A.M. ${ }^{1}$ and Afifi, M.M.I. ${ }^{2}$}

1- Plant Pathology Research Institute, Agricultural Research Center, 12619, Giza, Egypt.

2- Soils, Water and Environment Research Institute, Agricultural Research Center, 12619, Giza, Egypt.

R ean rust, caused by Uromyces appendiculatus, is one of the most

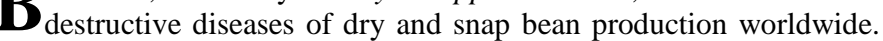
The present study aimed to investigate the efficacy of certain fungal and bacterial bio-agents in addition to some organic acids in comparison with fungicides to control bean rust under field conditions. Only fungal and bacterial bio-agents were tested for their inhibitory effect on uredospores germination in comparison with fungicides through in vitro trial. Growth parameters, total carbohydrates, chlorophyll, protein, and enzymes activity were assessed at the end of the trials for bean plants. The obtained results of in vitro trials indicated that Sumi-8 (EC 5\%) was the superior in inhibiting germination of uredospores followed by Topas 100 (EC) and B. subtilis with inhibition percentages 91, 84.6 and $81 \%$ inhibition, respectively. Results of field trials exhibited that treated bean plants with Sumi-8, Topas 100 and salicylic acid showed the lowest DS \% and AUDPC. Treatments of Trichoderma viride, T. asperellum and fulvic acid displayed moderate efficacy in reducing DS \% and AUDPC. All tested treatments resulted in considerable increase in growth parameters, total carbohydrates, chlorophyll, and protein in bean plants over control. Fulvic, citric and salicylic acids as well as $T$. viride were the most effective treatments in this regard. On the other hand, the highest activities of defense related enzymes i.e., peroxidase, polyphenoloxidase and catalase were recorded in treated bean plants with organic acids.

Keywords: Common bean, Phaseolus vulgaris, Uromyces appendiculatus, Fulvic, salicylic, ascorbic acids, citric acids, Trichoderma viride, T. harzianum, $T$. asperellum, Bacillus subtilis and B. pumilus.

Common bean (Phaseolus vulgaris L.) is the most important food legume for direct consumption in the world. Bean rust caused by Uromyces appendiculatus Pers. is dispersed worldwide and it is one of the most economically important diseases of common bean, causing yield losses that ranged from 25 to $100 \%$ in susceptible cultivars (Mmbaga et al., 1996; Steadman et al., 2002). The disease 
occurs on most dry and snap bean productions areas of the world especially in locations where humid to moderately humid conditions, long dew periods, and prevalent cool conditions during the bean growing season (El-Fawy and AboElyousr 2016). The disease is widely spread in different localities in Egypt during the last few years and it is managed mainly with fungicides (Tadrous et al., 2008). Control of bean rust is achieved using resistant cultivars (Alzate-Marin et al., 2004) and application of certain fungicides (Arslan et al., 2006). The use of plant resistance not only is harmless to the environment but also an economically sound strategy compared to chemical control. However, the wide variability of $U$. appendiculatus represents an obstacle to breeders aiming at the development of common bean cultivars with durable resistance to rust (Souza et al., 2013). At the same time, the cost involved in chemical pesticides is a major concern for farmers in developing countries. Moreover, complete disease control cannot be obtained by a single control measure where implementation of integrated disease and pest management programs is important for efficient disease control (Surviliene and Dambrauskiene, 2006).

Biological control of plant diseases has been considered as environmentally safe to protect plants against pathogens (Cook, 1993). The application of Trichoderma has proven fruitful against many soil-borne and foliar pathogens (Burmeister 2008; Jogaiah et al., 2018). Several studies highlighted the role of Trichoderma as biocontrol agents against pathogens causing leaf spots (Bigirimana et al., 1997; Abeysinghe, 2009). Bacillus species as a group having several advantages over other bacteria for protection against pathogens because of their abilities to form endospores as well as the broad-spectrum activity of their antibiotics (Saifeldeen $e t$ al., 2014). Recently numerous studies reported that the use of Bacillus strains as biocontrol agents could reduce amounts of chemical fungicides applied against phytopathogenic fungi (Nehra and Choudhary, 2015).

Organic acids had great variation in their molecular weights from relatively low molecular weights such as oxalic, malic and citric acids (Mimmo et al., 2008), to high molecular weight slikehumic and fulvic acids with enormous numbers of carboxylic and phenolic functional groups (Perminova et al., 2003). Organic acids play significant and varied roles in rhizosphere acidification and mineral weathering, contributing protons and serving as ligands that complex metals (Boyle and Voigt, 1973). In addition, organic acids as antioxidants play an important role in plant metabolism (Singh et al., 2010). Fulvic acid is a mixture of weak aliphatic and aromatic organic acids, which is soluble in water at all $\mathrm{pH}$ degrees. Fulvic acid enhances plant growth and productivity as well as, it has a great role against soil borne and foliar diseases (Afifi, 2010 and Said et al., 2014).

The present study aimed to investigate the efficacy of different fungal and bacterial bio-agents as well as some organic acids comparing to fungicides for controlling bean rust under field conditions.

Egypt. J. Phytopathol., Vol. 47, No. 1 (2019) 


\section{Materials and Methods}

Source of bean seeds:

Common bean seeds cv. Karnak were obtained from Vegetable Crops Research Department, Agricultural Research Centre (ARC), Giza, Egypt.

Source of tested organic acids:

Fulvic, salicylic, ascorbic, and citric acids were obtained from Soils, Water and Environment Research Institute (SWERI), Agricultural Research Centre (ARC), Giza, Egypt. Fulvic acid (FA) was extracted from fermented biogas manure which provided from Recycling of Agric. Residue Training Center, SWERI, ARC, Giza, Egypt, according to the method described by Sánchez-Monedero et al. (2002). Then, FA was purified according to the method described by Stevenson (1994).

Source of uredospores (Uromyces appendicculatus):

Uredospores were collected from leaves of common bean plants showing rust symptoms during the season 2017 in Badrcity center, Beheira governorate. The collected uredospores were dried and placed in micro tubes then stored under freezing conditions for further experiments. The collected uredospores were identified as $U$. appendicculatus based on the morphological description of Chung et al. (2004).

Source of used bio-agents:

Fungal and bacterial bio-agents were used as foliar spray to control common bean rust disease. Three species of Trichoderma; i.e., T. viride G6 SoR1, T. harzianum G2 NA and T. asperellum G4 IF2 were obtained kindly from fungal collection Bank in the Department of Vegetable Diseases Research, Plant Pathology Research Institute, ARC, Giza, Egypt, Also, two species of Bacillus; B. subtilis and B. pumilus were obtained kindly from SWERI, ARC, Giza, Egypt.

Source of used fungicides:

The tested fungicides, i.e., Topas 100 (EC) and Sumi-8 (EC 5\%) are shown in Table (1).

Table (1): Fungicides used in this study

\begin{tabular}{|c|c|c|c|c|}
\hline No. & Trade name & $\begin{array}{c}\text { Chemical } \\
\text { name }\end{array}$ & $\begin{array}{c}\text { Recommended } \\
\text { dose }\end{array}$ & Manufacture \\
\hline 1 & Topas 100 EC & Penconazole & $25 \mathrm{ml} / 100 \mathrm{~L}$. & $\begin{array}{c}\text { Syngenta UK Limited } \\
\text { Co. Switzerland }\end{array}$ \\
\hline 2 & Sumi-8 EC 5\% & Diniconazole & $35 \mathrm{ml} / 100 \mathrm{~L}$. & $\begin{array}{c}\text { Chematura Corparotion } \\
\text { Co. America }\end{array}$ \\
\hline
\end{tabular}


Experimental design:

The experimental design of 11 tested treatments (3 Trichoderma spp., 2 Bacillus spp., 2 fungicides and 4 organic acids) in addition to control treatment was achieved as a randomized complete block design (RCBD). The common bean seeds cv. Karnak were planted in 3 rows per plot in which 13 plants were maintained in each row. The space between plots was $0.6 \mathrm{~m}$ and plot size $1.8 \times 4.1 \mathrm{~m}\left(7.37 \mathrm{~m}^{2}\right)$, in which the plant-to-plant distance was $30 \mathrm{~cm}$ apart.

Effect of some biotic and abiotic factors on uredospore germination of $U$. appendiculatus in vitro:

In this trial, the tested bio-control agents i.e., T. viride G6 SoR1, T. harzianum G2 NAT. asperellum G4 IF2 were grown in sterilized 1-L conical flasks, each containing $200 \mathrm{~mL}$ of sterile potato dextrose broth (PDB) and incubated at $25 \pm 2{ }^{\circ} \mathrm{C}$ for 7-10 days for mass growth. The intended spore concentration $\left(10^{8}\right.$ spores $\left./ \mathrm{mL}\right)$ was prepared from the stock spore suspension with the aid of a hemocytometer slide. Bacterial suspensions of B. subtilis and B. pumilus were prepared from 24-hr cultures grown on nutrient agar at room temperature then they were adjusted microscopically to approximately $10^{9} \mathrm{CFU} / \mathrm{mL}$. The uredospores of the pathogen were added to each concentration of the tested bacterial and fungal bio-agents. One milliliter of uredospore suspension was placed on sterilized slide in a sterilized Petri dish (two slides in each). Plates were supplemented with a piece of wetted cotton by sterilized distilled water to maintain high relative humidity. A spore suspension supplemented with only sterilized distilled water served as control treatment. Plates were incubated in darkness at $24 \pm 1^{\circ} \mathrm{C}$ for $24 \mathrm{~h}$. Four Petri dishes for each treatment were used as replicates. The percent of germinated uredospores over control was calculated.

As for the effect of tested fungicides, an experiment was conducted to determine the effect of two fungicides i.e., Topas 100 (EC) and Sumi-8 (EC 5\%) with recommended rates (Table 1) on germination of uredospores on PDA medium. These tested fungicides were added to potato dextrose agar (PDA) medium after it had been autoclaved and cooled to approximately $50^{\circ} \mathrm{C}$. A volume of $50 \mu 1$ of spore suspension $\left(1 \times 10^{5} / \mathrm{mL}\right.$ uredospores) of $U$. appendiculatus was pipetted directly onto PDA amended with each of the two fungicides. Plates were then placed at $24 \pm 1^{\circ} \mathrm{C}$ in the dark for $24 \mathrm{~h}$. The percent of germinated uredospores over control was calculated as described before.

Effect of some biotic and abiotic factors on rust disease severity under field conditions:

The trial was carried out during the growing season 2018, on common bean plants cv. Karnak naturally infected with $U$. appendiculatus under field conditions. Planting of seeds was done on $25^{\text {th }}$ February 2018 by drilling two seeds per hole, then it was thinned after complete germination to keep one plant per hill. Spraying started on the first appearance of the disease symptoms 40 days after planting. Both

Egypt. J. Phytopathol., Vol. 47, No. 1 (2019) 
fungicides, Topas 100 (EC) and Sumi-8 (EC 5\%) were applied at recommended rates that specified on product labels (Table .1). Spore suspensions of $T$. viride G6 SoR1 and T. harzianum G2 NA (each at $10^{8}$ spores / $\mathrm{mL}$ ) and bacterial suspensions of B. subtilis and B. Pumilus $\left(10^{9} \mathrm{cfu} / \mathrm{mL}\right)$ and organic acids at concentration $2 \mathrm{mM}$ were applied as foliar spray four times with 10-days intervals. Control plants were sprayed with water only. Plants were well maintained with regular irrigation and fertilization. Disease severity (DS) was determined using the standard 1- 6 scale: 1 no pustules; 2 - necrotic spots without sporulation; 3 - pustules undergoing sporulation with a diameter of $<0.3 \mathrm{~mm} ; 4$ - pustules undergoing sporulation with a diameter ranging from $0.3 \mathrm{~mm}$ to $0.49 \mathrm{~mm} ; 5$ - pustules undergoing

$$
\mathrm{R}=[\Sigma(\mathrm{a} \times \mathrm{b}) /(\mathrm{N} \times \mathrm{K})] \times 100
$$

sporulation with a diameter ranging from $0.5 \mathrm{~mm}$ to $0.8 \mathrm{~mm}$; and 6 - pustules undergoing sporulation with a diameter of $>0.8 \mathrm{~mm}$ (Stavely et al., 1983). Disease severity was scored according to the equation described by Descalzo et al. (1990):

Where: $\mathrm{R}$-disease severity, $\mathrm{a}$-number of infected leaves rated, $\mathrm{b}$-numerical value of each grade, $\mathrm{N}$-total number of examined plants, $\mathrm{K}$-the highest degree of infection in scale.

Area Under Disease Progressive Curve (AUDPC) was calculated to compare amounts of disease among different treatments using the following equation of Pandey et al. (1989).

$$
\mathrm{AUDPC}=\mathrm{D}[1 / 2(\mathrm{Y} 1+\mathrm{Yk})+\mathrm{Y} 2+\mathrm{Y} 3+\ldots \ldots .+\mathrm{Y}(\mathrm{k}-1)]
$$

Where: $\mathrm{D}=$ days between readings, $\mathrm{Y} 1=$ first disease record, and $\mathrm{YK}=$ last disease record.

Determination of growth parameters of common bean plants:

Plant growth parameters i.e. plant height $(\mathrm{cm})$, number of pods and branches as well as weight $100 \mathrm{~g}$ of dry seeds were measured at the end of the trial.

Biochemical determinations in leaves of treated common bean plants:

In this respect, total carbohydrates were determined in the aqueous extract according to Dubois et al. (1956). While the total chlorophyll content was determined using the SPAD-501 portable leaf chlorophyll meter (Minolta Corp) for greenness measurements in the $5^{\text {th }}$ apical fully expanded leaf (Yadava 1986). On the other hand, the total protein content was determined according to the method of Leco Manuel (Thermal conductivity) by the Kjeldahl method. The nitrogen factor used for protein calculation was total nitrogen x 6.25 (AOAC, 2000).

Determination the activities of defense related enzymes:

The treated common bean plants were sampled after 48 hours of last treatment and analyzed for the activity of peroxidase and polyphenoloxidase, as indicators of fungal activities. The activity of peroxidase was measured calorimetrically based on the oxidation of pyrogallol to pyrogalline and using $\mathrm{H}_{2} \mathrm{O}_{2}$ at $425 \mathrm{~nm}$ (Thimmaiah, 
1999). Polyphenoloxidase activity was determined using colorimetric method of Maxwell and Bateman (1967). Catalase was determined by following the method of Aebi (1984).

\section{Statistical analysis:}

The data of DS \% and AUDPC, growth parameters and biochemical and enzymatic activities were subjected to ANOVA to determine treatment effect. Least significant difference (LSD) test was used to separate the treatment means. All data analyses were conducted using Web Agri Stat software Package (WASP) version 2.0.

\section{Results}

Effect of some biotic and abiotic factors on uredospore germination of $U$. appendiculatus in vitro:

The inhibitory effect of the tested antagonistic bio-agents and fungicides on germination of $U$. appendiculatus uredospores in vitro is shown in Table (2). According to LSD test values, there was significant $(\mathrm{P} \leq 0.05)$ variation among treatments in the number of the germinated uredospores. All tested treatments inhibited germination of uredospores comparing with control treatment. Results in Table (2) indicate that Sumi-8 fungicide was the most effective treatment in inhibiting germination of uredospores followed by Topas fungicide and B. subtilis, where they recorded $9.10,15.4$ and $19.04 \%$ of germination and $91,84.6$ and $81 \%$ of inhibition respectively. Whereas, the tested $T$. harzianum, T. viride, T. asperellum and $B$. pumilus came in the second rank where the recorded germination $\%$ ranged between $22.5-29.7 \%$ as well as the percentage of inhibition ranged from $70.3-77.5 \%$ comparing with the control treatment which recorded $88.99 \%$ germination.

Table (2): Effect of some biotic and abiotic factors on uredospores germination in vitro.

\begin{tabular}{|clcc|}
\hline Types & \multicolumn{1}{c}{ Treatments } & Germination $\%$ & Inhibition $\%$ \\
\hline \multirow{3}{*}{ Fungal bio-agents } & T. harzianum & 22.50 & 77.5 \\
& T. viride & 25.00 & 75.0 \\
& T. asperellum & 29.70 & 70.3 \\
\hline \multirow{2}{*}{ Bacterial bio-agents } & B. subtilis & 19.04 & 81.0 \\
& B. pumilus & 25.00 & 75.0 \\
\hline \multirow{2}{*}{ Fungicides } & Topas 100 & 15.40 & 84.6 \\
& Sumi-8 & 9.10 & 91.0 \\
\hline Control & & 88.99 & 11.01 \\
\hline LSD at 0.05 & & 2.734 & \\
\hline
\end{tabular}

Effect of biotic and abiotic factors on common bean rust in vivo

The inhibitory effect of the tested bio-agents, organic acids, and fungicides on the severity of common bean rust under field conditions is shown in Table (3).

Egypt. J. Phytopathol., Vol. 47, No. 1 (2019) 
Significant $(p \leq 0.05)$ differences were observed in the recorded DS \%and AUDPC among the tested treatments. In this respect, Sumi-8, Topas and Salicylic acid were the best treatments in controlling common bean rust infection where they recorded 28, 29 and $33 \%$ of DS and lowest AUDPC which being 715, 725 and $750 \%$, respectively at 70 days after planting.

Table (3): Effect of some biotic and abiotic factors on DS \% and AUDPC of bean rust in vivo

\begin{tabular}{|clccccc|}
\hline \multirow{2}{*}{ Types } & Treatments & $\begin{array}{c}40 \\
\text { day }\end{array}$ & $\begin{array}{c}50 \\
\text { day }\end{array}$ & $\begin{array}{c}60 \\
\text { day }\end{array}$ & $\begin{array}{c}70 \\
\text { day }\end{array}$ & AUDPC \\
\cline { 3 - 6 } & T. harzianum & 31 & 30 & 39 & 46 & 1075 \\
Fungal bio- & T. viride & 19 & 25 & 31 & 38 & 845 \\
agents & T. asperellum & 17 & 27 & 33 & 39 & 880 \\
\hline Bacterial bio- & B. subtilis & 22 & 28 & 37 & 42 & 970 \\
agents & B. pumilus & 20 & 29 & 36 & 47 & 985 \\
\hline \multirow{2}{*}{ Fungicides } & Topas 100 & 18 & 22 & 26 & 29 & 725 \\
& Sumi-8 & 21 & 23 & 25 & 28 & 715 \\
\hline \multirow{2}{*}{ Organic acids } & Ascorbic acid & 19 & 28 & 40 & 50 & 1025 \\
& Citric acid & 18 & 26 & 37 & 49 & 965 \\
& Fulvic acid & 20 & 30 & 34 & 40 & 940 \\
& Salicylic acid & 17 & 22 & 28 & 33 & 750 \\
\hline Control & & 17 & 40 & 65 & 80.2 & 1536 \\
\hline LSD at 0.05 & & & & 3.011 & & 82.785 \\
\hline
\end{tabular}

On the other hand, treatments with $T$. viride, T. asperellum and fulvic acid displayed moderate efficacy in reducing DS \%where they recorded $38,39,40 \%$, and AUDPC, being, 845, 880 and $940 \%$. The highest DS $\%$ and AUDPC were recorded with $T$. harzianum, B. pumilus, citric acid and ascorbic acid, where they scored the lowest efficacy in reducing severity of rust (Table 3 ). However, they still significantly $(\mathrm{P} \leq 0.05)$ effective when compared with control treatment. The highest DS \% and AUDPC values were recorded with the sprayed control plots with water only. The highly significant difference in AUDPC values among nearly all treatments indicated that they had variable impacts on common bean rust development.

Effect of some biotic and abiotic factors on some growth parameters of common bean plants in vivo

Data in Table (4) exhibit that all tested treatments enhanced the growth parameters of common bean plants in relation to the untreated control. The highest increase in plant height was recorded with fulvic acid followed by salicylic acid and 
citric acid, respectively without significant differences among the three tested organic acids. While ascorbic acid was the least effective in this respect with clear significant difference with the three tested other organic acids. On the other hand, Sumi-8 and Topas fungicides were the least effective treatments in increasing plant height followed by $T$. harzianum and B. pumilus as bioagent treatments. It is clear from the obtained results also that the three mentioned organic acids i.e., salicylic, fulvic and citric were the highest effective treatments among all other tested treatments in increasing No. of pods, No. of branches and weight of 100 seeds $(\mathrm{g})$ of treated common bean plants. On the other hand, B. subtilis, T. viride and $T$. asperellum were less effective and came in the second rank in increasing the previously mentioned growth parameters. Whereas Topas and Sumi- 8 were the least effective treatments in this respect.

Table (4): Effect of some biotic and abiotic factors on some growth parameters of treated common bean plants in vivo

\begin{tabular}{|llcccc|}
\hline \multicolumn{1}{|c}{ Types } & \multicolumn{1}{c}{ Treatment } & $\begin{array}{c}\text { Plant } \\
\text { height } \\
(\mathrm{cm})\end{array}$ & $\begin{array}{c}\text { No. of } \\
\text { pods }\end{array}$ & $\begin{array}{c}\text { No. of } \\
\text { branches }\end{array}$ & $\begin{array}{c}\text { Weight } \\
100 \\
\text { seeds }(\mathrm{g})\end{array}$ \\
\hline \multirow{2}{*}{ Fungal } & T. harzianum & 37.7 & 10.1 & 5.1 & 61.03 \\
bio-agents & T. viride & 41.2 & 19.3 & 6.7 & 62.15 \\
& T. asperellum & 39.6 & 17.6 & 5.2 & 61.53 \\
\hline Bacterial & B. subtilis & 40.1 & 14.1 & 6.3 & 62.27 \\
bio-agents & B. pumilus & 38.2 & 16.4 & 5.1 & 59.67 \\
\hline \multirow{2}{*}{ Fungicides } & Topas 100 & 36.9 & 15.3 & 4.8 & 59.12 \\
& Sumi -8 & 36.3 & 14.3 & 4.9 & 58.29 \\
\hline \multirow{3}{*}{ Organic } & Ascorbic acid & 39.1 & 17.5 & 5.3 & 61.18 \\
acids & Citric acid & 42.4 & 20.3 & 6.9 & 68.92 \\
& Fulvic acid & 44.7 & 22.5 & 7.2 & 64.03 \\
\hline Control & Salicylic acid & 43.6 & 23.2 & 7.3 & 64.75 \\
\hline LSD at 0.05 & & 30.3 & 9.7 & 3.1 & 49.23 \\
\hline
\end{tabular}

Effect of some biotic and abiotic factors on some biochemical content of treated common bean plants in vivo:

Data in Table (5) reveal that all total chlorophyll, carbohydrates, and protein in leaves of common bean plants cv. Karnak were increased greatly in response to all tested biotic and abiotic treatments comparing with the control treatment. Results indicate also that fulvic and citric acid treatments were the best among the tested biotic and abiotic treatments in increasing the content of total chlorophyll where they recorded 24.9 and 24.4, respectively. Moreover, all treatments resulted in Egypt. J. Phytopathol., Vol. 47, No. 1 (2019) 
considerable increase in total carbohydrates. Trichoderma viride and fulvic acid were the best where both recorded $3.4 \mathrm{mg} / \mathrm{g}$ dry weight. Also, among the tested treatments, fulvic and citric acids revealed the highest increase in total protein where they recorded up to 29.4 and $29.1 \mathrm{mg} / \mathrm{g}$ dry weight, respectively.

Table (5): Effect of some biotic and abiotic factors on some biochemical contents of treated common bean plants in vivo.

\begin{tabular}{|llccc|}
\hline \multicolumn{1}{|c}{ Types } & Treatment & $\begin{array}{c}\text { Total } \\
\text { Chlorophyll } \\
\text { (SPAD) }\end{array}$ & $\begin{array}{c}\text { Total } \\
\text { Carbohydrates } \\
\text { (mg/g dry } \\
\text { weight }\end{array}$ & $\begin{array}{c}\text { Total Protein } \\
\text { (mg/g dry } \\
\text { weight }\end{array}$ \\
\hline Fungal bio- & T. harzianum & 17.3 & 2.8 & 26.7 \\
agents & T. viride & 22.2 & 3.4 & 28.2 \\
& T. asperellum & 19.6 & 2.9 & 26.9 \\
\hline Bacterial & B. subtilis & 21.5 & 3.1 & 27.2 \\
bio-agents & B. pumilus & 18.3 & 2.8 & 26.8 \\
\hline \multirow{2}{*}{ Fungicides } & Topas 100 & 19.2 & 2.6 & 26.1 \\
& Sumi-8 & 15.1 & 2.5 & 25.3 \\
\hline \multirow{2}{*}{ Organic } & Ascorbic acid & 19.2 & 3.1 & 27.3 \\
acids & Citric acid & 24.6 & 3.1 & 29.1 \\
& Fulvic acid & 24.9 & 3.4 & 29.4 \\
\hline Control & Salicylic acid & 22.3 & 2.9 & 27.2 \\
\hline LSD at 0.05 & & 11.3 & 2.1 & 20.1 \\
\hline
\end{tabular}

Effect of some biotic and abiotic factors on activities of some defense enzymes in treated common bean plants in vivo

Results in Table (6) indicate that all tested bio-agents, organic acids, and fungicides increased significantly $(\mathrm{P} \leq 0.05)$ the activities of peroxidase, polyphenoloxidase and catalase enzymes in leaves of common bean plants compared with untreated control. In this respect, fulvic acid was the superior treatment in increasing activities of defense enzyme peroxidase where the recorded value was $0.992 \mathrm{mg} / \mathrm{ml}$. Meanwhile, T. harzianum was the best treatment in increasing the activity of polyphenoloxidase enzyme where it recorded the highest value to be $0.331 \mathrm{mg} / \mathrm{ml}$. On the other hand, B. pumilus treatment was the best where it significantly increased the catalase enzyme activity to be $0.245 \mathrm{mg} / \mathrm{ml}$. 
Table (6): Effect of some biotic and abiotic factors on activities of some defense enzymes in leaves of treated common bean plants in vivo.

\begin{tabular}{|llccc|}
\hline \multicolumn{1}{|c}{ Types } & Treatment & $\begin{array}{c}\text { Peroxidase } \\
(\mathrm{mg} / \mathrm{ml})\end{array}$ & $\begin{array}{c}\text { Polyphenol } \\
\text { oxidase } \\
(\mathrm{mg} / \mathrm{ml})\end{array}$ & $\begin{array}{c}\text { Catalase } \\
(\mathrm{mg} / \mathrm{ml})\end{array}$ \\
\hline \multirow{3}{*}{ Fungal bio-agents } & T. harzianum & 0.712 & 0.331 & 0.242 \\
& T. viride & 0.513 & 0.295 & 0.233 \\
& T. asperellum & 0.916 & 0.283 & 0.223 \\
\hline \multirow{2}{*}{ Bacterial bio-agents } & B. subtilis & 0.810 & 0.273 & 0.238 \\
& B. pumilus & 0.621 & 0.253 & 0.245 \\
\hline \multirow{2}{*}{ Fungicides } & Topas 100 & 0.865 & 0.233 & 0.198 \\
\hline \multirow{3}{*}{ Organic acids } & Sumi-8 & 0.895 & 0.210 & 0.196 \\
\hline Control & Ascorbic & 0.913 & 0.297 & 0.232 \\
& Citric acid & 0.699 & 0.252 & 0.222 \\
\hline LSD at 0.05 & Fulvic acid & 0.992 & 0.293 & 0.216 \\
& Salicylic acid & 0.862 & 0.299 & 0.225 \\
\hline
\end{tabular}

\section{D i s c us sion}

Biological control is considered an important approach in the recent years for controlling many fungal plant pathogens. In this context, the potential antagonistic effect of certain bio-agents was evaluated through in vitro trial against germination of uredospores over certain fungicides. In this respect, all tested treatments inhibited the germination of uredospores over control. The obtained results showed that $B$. subtilis resulted in maximum germination inhibition (81\%) of $U$. appendiculatus uredospores over other tested bio-agents. This finding is supported by the earlier study of Mizubuti et al. (1995) who demonstrated that five strains of B. subtilis exhibited significant reduction in the germination of $U$. appendiculatus uredospores. Unlike, Zyton and Hassan (2017) demonstrated that B. thuringiensis had the greatest inhibitory effect that reached $74.7 \%$ and B. subtilis showed a moderate effect $59.4 \%$ against uredospores of $U$. pisi, the causal of pea rust. Under field conditions, Baker et al. (1985) observed a reduction of at least $75 \%$ of rust occurrence upon three weekly applications of the strains APPL-1 and PPL-3 of B. subtilis.

The inhibitory activity results of the tested Trichoderma on the development of germ tube of the $U$. appendiculatus were also promising. According to statistical analysis, there was no great variation among Trichoderma species in terms of inhibiting uredospores germination. T. harzianum exhibited the greatest inhibition followed by $T$. viride. Our finding is supported by the comprehensive study of Burmeister (2008) who demonstrated also that six T. harzianums trains were able to inhibit germination and development of germ tube of $U$. appendiculatus

Egypt. J. Phytopathol., Vol. 47, No. 1 (2019) 
uredospores. Unlike, Zyton and Hassan (2017) demonstrated that T. viride was the best in inhibiting uredospore germination of $U$. appendiculatus with efficacy reached $61.4 \%$ followed by $T$. harzianum $53 \%$. Moreover, El-Sharkawy et al. (2018) found out that the highest inhibition percentage was achieved by either spore suspension or cell-free filtrate of $T$. harzianum HL1 $+T$. viride HL5 against uredospores of $P$. graminis f.sp. tritici the causal agent of stem rust disease of wheat. Moreover, the earlier study of Baker et al. (1985) confirmed that application of Trichoderma spp., Pseudomonas spp., and B. subtilis on bean leaves resulted in reduction of rust incidence. It is important also to assume that Trichoderma can act as resistance inducer and this was reported in the study of Abeysinghe (2009) who attributed the suppressive effect of $T$. harzianum RU01 to the induction of systemic resistance of bean plants. Concluding, the mechanisms of systemic resistance induced by biocontrol agents are reported to be varied among the inducing agents (Van Loon, 2007).

The reported results confirmed that among organic acids tested; salicylic acid was the best in reducing disease severity of rust over bio-agent and untreated control. This agreed with the statement of Abeysinghe (2009) who confirmed that salicylic acid exhibited the highest resistance level against rust disease compared to T. harzianum RU01. In contrast, El-Fawy and Abo-Elyousr (2016), mentioned that the highest level of common bean rust reduction was recorded for $8 \mathrm{mM}$ of benzoic acid treatment compared to the other tested compounds. On the other hand, Mohamed et al. (2015) demonstrated that ascorbic, acetic, and boric acids followed by salicylic acid at their higher concentrations were mostly effective against grey mold and cottony rot caused by $B$. cinerea. Overall, in plants, the application of salicylic acid operates various physiological, biochemical, and molecular processes which play a key role in defense response and induction of certain enzymes (Chen $e t$ al., 2006).

The tested organic acids: citric, fulvic and salicylic acids were the superior followed by bio-agents that caused a significant increase of common bean growth parameters over fungicide treatment and untreated control. In a detailed study, El Shewy (2019), found that application of Trichoderma species, salicylic, ascorbic, and oxalic acids significantly increased growth and yield of potato. In a similar study, Mohamed et al. (2012) mentioned that using of Trichoderma species, $B$. subtilis and salicylic acid were effective in increasing the yield of onion. Consistently, Sadeghipour and Aghaei (2012) showed that application of salicylic acid at $0.5 \mathrm{mM}$ improved plant height by $6 \%$ and yield of common bean under water stress conditions. The tested bio-agents and organic acids had significant results in increasing total chlorophyll, total carbohydrates, and total proteins in bean plants. Our results exhibited that $T$. viride, B. subtilis, fulvic and salicylic acids were the superior treatments that resulted in an increase in the total chlorophyll, carbohydrates, and protein in leaves of bean plants. Similar results were reported by Azaemi et al. (2011) who indicated that chlorophyll content was increased in treated 
tomato seedlings with Trichoderma sp. Recently, Sarhan et al. (2018) reported that salicylic acid (SA), B. subtilis and T. harzianum as seed treatments of snap bean increased defense-related enzymes peroxidase and polyphenoloxidase, and significantly increased vegetative characteristics and yield parameters, as well as, chemical composition of green pods showed a significant increase in protein and carbohydrates content.

The role of salicylic acid could be discussed in light of the findings of Hayat et al. (2013) who indicated that improvement of plant height may be related to improve mitosis, cell division and cell elongation due to salicylic acid effects on the biosynthesis and activities of plant hormones ethylene, abscisic acid and cytokinin. Likewise, Stewart and Hill (2014) indicated that Trichoderma have various mechanisms to explain growth promotion, i.e. increase carbohydrate, metabolism, photosynthesis and phytohormone synthesis. It has also been reported that Trichoderma produces auxin-like compounds (Contreras-Cornejo et al., 2009). Mehanna et al. (2013) stated in their investigations that improvement of plant growth in response to organic acids application was due to osmoregulatory role of these organic solutes which help the plants to absorb more water.

Also, all tested treatments enhanced the activities of oxidative enzymes in bean plants with differences. Spraying common bean plants with fulvic and ascorbic followed by salicylic acids were the effective treatments in increasing peroxidase and polyphenoloxidase comparing with other treatments. Similarly, Lotfi et al. (2015) found that the foliar application of fulvic acid improved the peroxidase activity in rapeseed plants. On the other hand, Hassan et al. (2007) found that citric and benzoic acids were very effective and resulted in the highest levels of peroxidase activity that reached up to two-folds of the control treatment. Also, Mohamed et al. (2012) stated that T. harzianum, salicylic acid produced the highest level of peroxidase and polyphenoloxidase enzymes activity in leaf tissues of cowpea healthy plants. According to Abdul Rashid et al. (2011), salicylic acid, as plant hormone plays an important role in inducing plant defense system against a variety of biotic and abiotic stresses through morphological, physiological, and biochemical mechanisms. El-Shewy (2019) found that salicylic, ascorbic, and oxalic acids and Trichoderma spp. had positive effect in increasing polyphenoloxidase, peroxidase and catalase enzymes activity in potato leaves and tubers.

\section{References}

Abdul Rashid, W.; Paulraj, M.G.; War, M.Y. and Ignacimuthu, S. 2011. Role of salicylic acid in induction of plant defense system in chickpea (Cicer arietinum L.). Plant. Signal. Behav., 6(11): 1787-1792.

Abeysinghe, S. 2009. Systemic resistance induced by Trichoderma harzianum RU01 against Uromyces appendiculatus on Phaseolus vulgaris. J. Natn. Sci. Foundation Sri Lanka, 37(3): 203-207.

Egypt. J. Phytopathol., Vol. 47, No. 1 (2019) 
Aebi, H. 1984. In: Catalase in vitro. Methods in Enzymology Colowick SP, Kaplan NO, editors. Vol. 105. Florida: Acad. Press, pp. 114-121.

AOAC. 2000. Official Methods of Analysis of Association of Official Analytical Chemists, $15^{\text {th }}$ ed., AOAC, Arlington, Virginia, USA.

Afifi, M.M.I. 2010. Biochemical Studies on Humic Substances Extracted from Organic Fertilizers. PhD Thesis, Faculty of Agriculture, Cairo University p.137.

Alzate-Marin, A.L.; De Soza, T.L.P.O.; Ragagnin, V.A.; Moreira M.A. and De Barros E.G. 2004. Allelism tests between the rust resistance genes present in common bean cultivar Ouro Negro and genes Ur-5 and Ur-11. J. Phytopathol., 152: $60-64$.

Arslan, U.; Ilhan K. and Karabulut, O.A. 2006. Evaluation of food additives and low-toxicity compounds for the control of bean rust and wheat rust. $J$. Phytopathol., 154: 534-541.

Azaemi, R.; Hajieghrari, B. and Giglou, A. 2011. Effect of Trichoderma isolates on tomato seedling growth response and nutrient uptake. Afr. J. Biotechnol., 10(31): $5850-5855$

Baker, C.J.; Stavely, J.R. and Mock, N. 1985. Biocontrol of bean rust by Bacillus subtilis under field conditions. Plant Dis., 69:770-772.

Bigirimana, J.; Meyer, G.; De Poppe, J.; Elad, Y. and Hofte, M. 1997. Induction of systemic resistance on the bean (Phaseolus vulgaris) by Trichoderma harzianum. Faculty of Medicine and Health Sciences, Ghent University, 62: 1001-1007.

Boyle, J.R. and Voigt, G.K. 1973. Biological weathering of silicate minerals. Plant Soil., 38: 191-201.

Burmeister, L. 2008. The antagonistic mechanisms employed by Trichoderma harzianum and their impact on the control of the bean rust fungus Uromyces appendiculatus. PhD Thesis, University of Hannover, pp.135.

Chen, J.Y.; Wen, P.F.; Kong, W.F.; Pan, Q.H.; Zhan, J.C.; Li, J.M.; Wan, S.B. and Huang, W.D. 2006. Effect of salicylic acid on phenylpropanoids and phenylalanine ammonialyase in harvested grape berries. Postharvest Biol. Technol., 40: 64-72.

Chung, W.H.; Tsukiboshi, T.; Ono, Y. and Kakishima, M. 2004. Morphological andphylogenetic analyses of Uromyces appendiculatus and $U$. vignae on legumes in Japan. Mycoscience., 45: 233-244.

Contreras-Cornejo, H.A.; Macías-Rodríguez, L.I.; Cortés-Penagos, C. and LópezBucio, J. 2009. Trichoderma virens, a plant beneficial fungus, enhances biomass 
production and promotes lateral root growth through an auxin-dependent mechanism in Arabidopsis. Plant Physiol., 149: 1579-1592

Cook, R.J. 1993. Making greater use of introduced microorganisms for biological control of plant pathogens. Anпи. Rev. Phytopathol., 31: 53-80.

Descalzo, R.C.; Rohe, J.E. and Mauza, B. 1990. Comparative efficacy of induced resistance to selected diseases of greenhouse cucumber. Can. J. Plant. Pathol., 12: 69-79.

Dubois, M.; Gilles, K.; Hamilton, J.; Rebers, P. and Smith, F.1956. Colorimetric method for determination of sugars and related substances. Anal. Chem., 28(3): 350-356.

El-Fawy, M.M. and Abo-Elyousr K.A.M. 2016. Efficacy of certain chemical compounds on common bean rust disease.Arch. Phytopathology. Plant. Protect., 49: 522-532.

El-Sharkawy, H.H.A.; Rashad, Y. and Ibrahim S.A. 2018. Biocontrol of stem rust disease of wheat using arbuscular mycorrhizal fungi and Trichoderma spp. Physiological and Molecular Plant Pathol., 103: 84-91.

EL-Shewy, S.E. 2019. Integrated Control of Black Scurf Disease of Potato. Ph.D. Thesis, Faculty of Agriculture, Universityof Benha, pp.156.

Hassan, M.E.M.; El-Rahman, S.S.A.; El-Abbasi, I.H. and Mikhail, M.S. 2007. Changes in peroxidase activity due to resistance induced against faba bean chocolate spot disease. Egyp. J. Phytopathol., 35: 35-48.

Hayat, S.; Ahmad, A. and Alyemeni M.N. 2013. Salicylic Acid: Plant Growth and Development. Springer, Dordrecht, The Netherlands, pp.389.

Jogaiah, S; Abdelrahman, M; Tran, L.P. and Ito S. 2018. Different mechanisms of Trichoderma virens-mediated resistance in tomato against Fusarium wilt involve the jasmonic and salicylic acid pathways. Mol. Plant Pathol., 19:870-882.

Lotfi, R.; Pessarakli, M.; Gharavi-Kouchebagh, P. and Khoshvaghti, H. 2015. Physiological responses of Brassica napus to fulvic acid under water stress: Chlorophyll a fluorescence and antioxidant enzyme activity. Crop J., 3:434 439.

Maxwell, D.P. and Bateman, D.F. 1967. Changes in the activity of some oxidases in extracts of Rhizoctonia infected bean hypocotyls in relation to lesion maturation. Phytopathology, 57: 132-136.

Mehanna, H.M.; Hussein, M.M. and Gafaar N.A. 2013. Using of growth regulators for improving water use of canola under water deficit. Middle East J. Appl. Sci., 3(4): 161-168.

Mimmo, T.; Ghizzi, M.; Marzadori, C. and Gessa, C.E. 2008. Organic acid extraction from rhizosphere soil: effect of field-moist, dried and frozen samples. Plant Soil., 312: 175-184.

Egypt. J. Phytopathol., Vol. 47, No. 1 (2019) 
Mizubuti, E.S.G.; Maffia, L.A.; Muchovej, J.J.; Romeiro, R.S. and Batista, U.G. 1995. Selectionof isolatesof Bacillus subtilis with potential for the control of dry bean rust. Fitopatol. Bras., 20:540- 544.

Mmbaga, M.T.; Steadman, J.R. and Eskridge, K.M. 1996. Virulence patterns of Uromyces appendiculatus from different geographical areas and implications for finding durable resistance to rust of common bean. J. Phytopathol., 144(1112):533-541.

Mohamed, G.M.; Muhanna, N.A.S.; Ragab, S.S.M. and Kamal S.M.H. 2012. Evaluation of some environmentally safe chemicals and bioagent against Fusarium solani and sclerotium infected cowpea plants. J. Plant Prot. Path., 3:1299-1319.

Mohamed, F.G.; Abdel-Mageed, M.H.; Hafez, M.S.; Soltan H.H.; Rashid, I.A. and Abdel-Rahman, F.A. 2015. Effect of some organic acids on anatomical, physiological changes and post-harvest diseases od snap bean pods. J. Boil. Chem. Environ. Sci., 3:287-311.

Nehra, V. and Choudhary, M. 2015. A review on plant growth promoting rhizobacteria acting as bioinoculants and their biological approach towards the production of sustainable agriculture. J. Appl. Nat. Sci., 7(1):540-556.

Pandey, H.N.; Menon, T.C.M. and Rao, M.V. 1989. A simple formula for calculating area under disease progress curve. Rachis., 8(2): 38-39.

Perminova, I.V.; Frimmel, F.H.; Kudryavtsev, A.V.; Kulikova, N.A.; Abbt-Braun, G.; Hesse, S. and Petrosyan, V.S. 2003. Molecular weight characteristics of humic substances from different environments as determined by size exclusion chromatography and their statistical evaluation. Environ. Sci. Technol., 37: 24772485.

Sadeghipour, O. and Aghaei, P. 2012. The role of exogenous salicylic acid (SA) on phytohormonal changes and drought tolerance in common bean (Phaseolus vulgaris L.) J.Biodivers Environ. Sci., 2(12): 8-15.

Said, M.K.1.; Afifi, M.M.I.; El-Shoraky, F.S. and El-Sawy, M.M. 2014. Fulvic acid: a tool for controlling powdery and downy mildews in cucumber plants. Int. $J$. Phytopathol., 3(2): 101-108.

Saifeldeen, A.A.; Soad, A.A.A.; Elshiekh, A.I. and Ahmed M.E.2014. In Vitro screening of Bacillus isolates for biological control of early blight disease of tomato in Shamb at Soil. World J. Agric. Res., 2(2): 47-50.

Sánchez-Monedero, M.A.; Cegarra, J.; García, D. and Roig, A. 2002. Chemical and structural evolution of humic acids during organic waste composting. Biodegradation., 13: 361-371.

Sarhan E.A.D.; El-Far, E.M.M. and Ebrahiem, A.M.Y. 2018. Systemic resistance in snap bean (Phaseolus vulgaris L.) elicited by some chemicals and biotic inducers 
against white mold disease caused by (Sclerotinia sclerotiorum). Egypt J. Phytopathol., 46(2): 61-84.

Singh, K.P.; Chaturvedi, V.K. and Bose, B. 2010. Effects of salicylic acid on seedling growth and nitrogen metabolism in cucumber (Cucumis sativa L.). $J$. Stress Physiol. Bioch., 6(3): 102-113.

Souza, T.L.P.O.; Faleiro, F.G.; Dessaune, S.N.; Paula-Junior, T.J.de.; Moreira, M.A. and Barros, E.G. de. 2013. Breeding for common bean (Phaseolus vulgaris L.) rust resistance in Brazil. Trop. Plant Pathol., 38(5): 361-374.

Stavely, J.R.; Freytag, G.F.; Steadman, J.R. and Schwartz, H.F. 1983. The 1983 Bean Rust Workshop. Annu. Rep. Bean Improv. Coop., 26:4-6.

Steadman, J.R.; Pastor-Corrales, M. A. and Beaver, J.S. 2002. An overview of the $3^{\text {rd }}$ Bean rust and $2^{\text {nd }}$ Bean Common Bacterial Blight International Workshops. Annu. Rep. Bean Improv. Coop., 45:120-124.

Stevenson, F.J. 1994. Humus Chemistry, Genesis, Composition, Reaction. pp512. John Wiley and Sons, New York.

Stewart, A. and Hill, R. 2014. Applications of Trichoderma in Plant Growth Promotion, (eds): Vijai K.G.; Schmoll, M.; Herrera-Estrella, A.; Upadhyay, R.S.; Druzhinina, I. and Tuohy, M.G. In: Biotechnology and Biology of Trichoderma, Elsevier, pp. 415-428.

Survilienè, E. and Dambrauskienè, E. 2006. Effect of different active ingredients of fungicides on Alternaria spp. growth in vitro. Agron. Res., 4: 403-406.

Tadrous, A.Z.; Yhia, A.S. and Khalil, M.N.A. 2008. Integrated control of common bean rust in relation to vegetative growth, pod characteristics and total green yield. Egypt J. Appl. Sci., 17:327-345.

Thimmaiah, S.R. 1999. Standard Methods of Biochemical Analysis. Pp.230-231. Kalyani Publishers New Dilhi.

Van Loon, L.C. 2007. Plant responses to plant growth promoting rhizobacteria. Eur. J. Plant Pathol., 119: 243-254.

WASP, (Web Agri Stat Software) Vers. 2.0., https://ccari.res.in/wasp2.0/index.php.

Yadava, U.L. 1986. A rapid and nondestructive method to determine chlorophyll in intact leaves. Hort Science., 22:1449-1450.

Zyton, M.A. and Hassan, E.O. 2017. Effect of the combination between bioagents and benzothiadiazole (BTH) on management of Uromyces pisi the causal of pea rust. Am. J. Life Sci., 5(3-1): 15-23.

Corresponding author: Ismail, A.M

E-mail: ma.ah.ismail@gmail.com

(Received 25/01/2019;

in revised form 10/02/2019)

Egypt. J. Phytopathol., Vol. 47, No. 1 (2019) 
كفاءة العوامل الحيوية وغير الحيوية في مكافحة مرض إضول

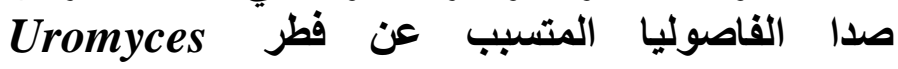
appendiculatus

احمد محمود إسماعيل 1 ، حمحد محمود ابراهيم عفيفي2 1- معهر بحوث أمراض النباتات ، مركز البحوث الزراعية ، مدود الجيزة ،

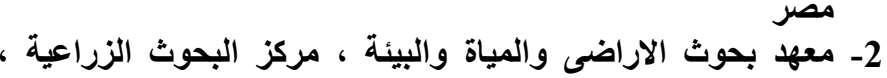

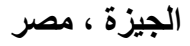

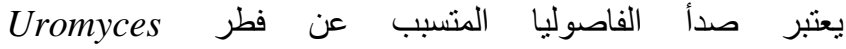

appendiculatus

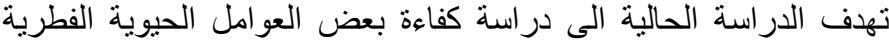

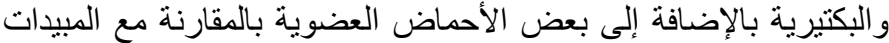

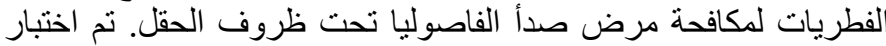

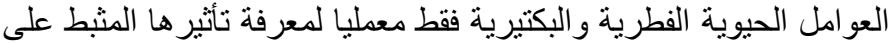

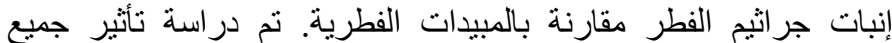

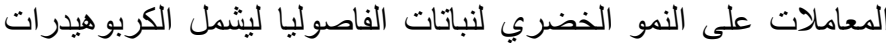

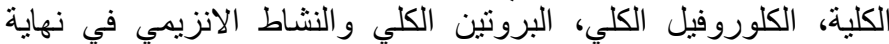

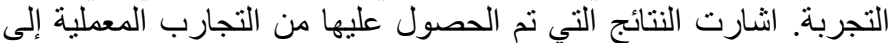

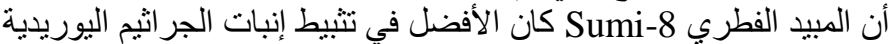

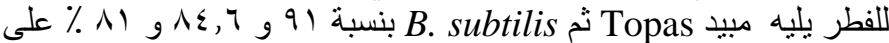

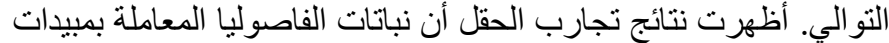

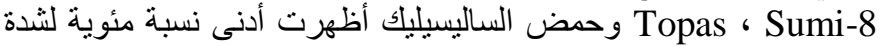

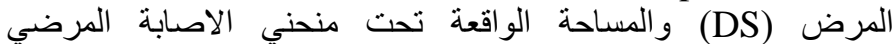

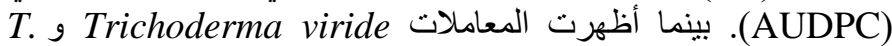

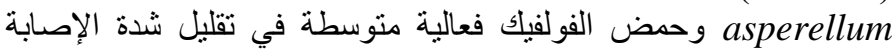

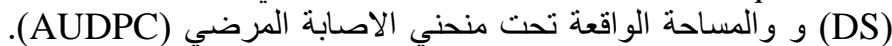

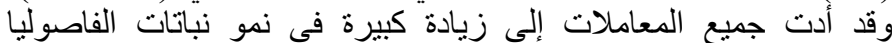

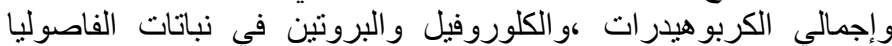

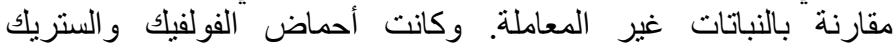

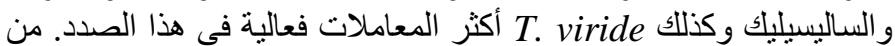

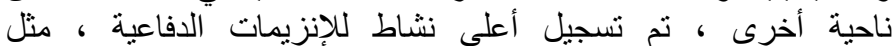

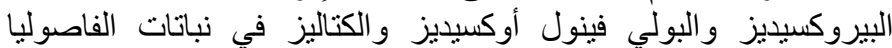
المعاملة بالأحماض العضوية. 